\title{
Influence of disinfectant solutions on test materials used for the determination of masticatory performance
}

\begin{abstract}
Simone Silvério Campos ${ }^{(a)}$ Cássio Vicente Pereira ${ }^{(a)}$ Márcio Gilberto Zangerônimo(b) Leandro Silva Marques(c) Luciano José Pereira(b)
\end{abstract}

\footnotetext{
(a) Curso de Odontologia, Centro Univ de Lavras - UNILAVRAS, Lavras, MG, Brasil.

(b) Departamento de Medicina Veterinária, Setor de Fisiologia e Farmacologia, Univ Federal de Lavras - UFLA, Lavras, MG, Brazil.

(c) Department of Orthodontics, School of Dentistry, Univ Federal dos Vales do Jequitinhonha e Mucuri - UFVJM, Diamantina, MG, Brazil.
}

\begin{abstract}
Masticatory function can be evaluated objectively as the capacity of an individual to fragment solid food after a fixed number of chewing cycles, the so-called masticatory performance (MP). The objective of this study was to evaluate the reliability of four different test materials (Optosil, Optocal, Zetapuls, and Perfil) and five disinfection protocols by aspersion and immersion (no disinfection, $2 \%$ glutaraldehyde, $2 \%$ chlorhexidine, $5.25 \%$ sodium hypochlorite, and $70 \%$ alcohol) on the MP, determined at three moments (24 hours, 15 and 60 days) after storing the fragmented blocks. MP was evaluated by calculating $\mathrm{X}_{50}$ through the sieving technique and the Rosim-Ramler equation. The weight and microbiologic count (colony forming units, CFUs) of chewed blocks were measured to identify any variations that would make MP determination unfeasible. Differences in MP were observed among the materials $(p<0.01)$. Perfil presented the highest $\mathrm{X}_{50}$ value (worst MP determination), followed by Zetaplus (both $p<0.05$ ), Optosil, and Optocal (both $p>0.05$ ). The time and disinfection type had no influence on MP $(p>0.05)$. The number of CFUs differed between the nondisinfected group and all other disinfection groups at all time points $(p<0.01)$. No other significant difference in CFU count between disinfection groups was observed. In conclusion, disinfection did not alter the reliability of the test materials for the MP calculation for up to 60 days.
\end{abstract}

Descriptors: Mastication; Disinfection; Dental Materials.

\section{Introduction}

During mastication, food is broken down into smaller particles to facilitate enzymatic processing and swallowing. ${ }^{1,2}$ Although masticatory function can be measured by various means, masticatory performance (MP) testing is the most commonly used objective method. MP is defined as the capacity of an individual to fragment a solid natural or artificial test food during mastication. ${ }^{3} \mathrm{~A}$ decline in MP may result in changes in the diet, as some foods become difficult to eat. ${ }^{4-7}$

The test material used to determine MP should provide an ideal bolus for the scientific study of mastication. ${ }^{3,8-12}$ A natural food has the advantage that it is normally consumed. However, the consistency of the food may vary due to seasonal and geographical influences, and the food may
Submitted: Oct 31, 2012

Accepted for publication: Feb 05, 2013

Last revision: Mar 11, 2013 
deteriorate during storage. ${ }^{12}$ On the other hand, impression materials are potential sources of bacterial contamination, which can lead to the transmission of infectious diseases through the saliva or blood from the oral cavity. ${ }^{13}$ During the clinical routine for MP determination, disinfection techniques can be applied ${ }^{14}$ to minimize the risk of contamination. Nevertheless, the use of disinfection may result in weight alterations, creating the possibility of error in the MP determination.

The objective of this study was to evaluate the accumulation of microorganisms in four different test materials and the utility of five disinfection protocols. Additionally, the materials were appraised as to the degree of weight variation by the sieving process for the MP calculation at different times.

\section{Methodology Materials}

This study was approved by the local ethics research committee (CAAE, 0041.0.189.000-09). MP blocks were made of an acrylic matrix and stainless stee ${ }^{15}$ and were manipulated according to the manufacturer's specifications. The following test materials were used:

1. Optosil Comfort (Heraeuz Kulzer, Hanau, Germany; Lot: R270493);

2. Optocal, comprised of

- casting silicone (57\%; Optosil),

- toothpaste (27\%; Sorriso Super Refrescante, Colgate-Palmolive Commercial Ltda., São Paulo, Brazil),

- solid petroleum gel (3\%, 30g; Rioquímica, São José do Rio Preto, Brazil),

- type V dental plaster (Polidental, Cotia, Brazil),

- irreversible hydrocolloid type 1 fast-setting alginate (4\%; Jeltrate Plus, Dentisply, Milford, USA), and

- catalytic paste (27 mg; Optosil); ;6,17

3. Perfil (Vigodent, Rio de Janeiro, Brazil; Lot: 140/08); and

4. Zetaplus (Zhermack, Badia Polesine, Italy; Lot: 78828).

Materials were disinfected by immersion and as- persion as follows:

- no disinfection;

- 2\% glutaraldehyde solution (Glutaron, Pharmaceutical Industry Rioquímica Ltda., São José do Rio Preto, Brazil),

- $5.25 \%$ sodium hypochlorite solution (Clorox, The Clorox Company, Oakland, USA);

- $2 \%$ chlorhexidine solution (Verde Vida Pharmacy, Lavras, Brazil); and

- 70\% alcohol solution (Start, Lima and Pergher Ind. Com. Rep. Ltda., Uberlândia, Brasil).

The accumulation of microorganisms and the weights of the materials in each disinfection group were evaluated immediately, 15 days, and 60 days after mastication.

\section{Measurement of MP}

The MP was evaluated by determining the capacity of an individual to fragment the artificial test food. ${ }^{18}$ A single subject received 17 cubes of each material at each collection moment. Each cube was chewed for 20 masticatory cycles per collection moment. The study subject had all of his permanent teeth (12 occlusal units), a mesocephalic facial pattern, and an Angle Class I molar relationship, was free of any systemic disease that would interfere with motor activities, and did not use any medicine that would impact saliva secretion.

The number of masticatory cycles was visually quantified by the examiner. The triturated particles were expelled from the oral cavity into plastic containers with the aid of a funnel and disinfected with one of the 5 different protocols. The particles were placed on filter paper for drying. Dried particles were removed from the filter paper and passed through a series of 10 granulometric sieves, with the diameters of the openings ranging from 5.6 to $0.71 \mathrm{~mm}$, in decreasing order. The particle distribution by weight was described by the cumulative function of the average size of the particles, $\mathrm{X}_{50} \cdot{ }^{19,20}$

\section{Microbiological analysis}

Each material used with each disinfectant was analyzed. The fragments were placed in a test tube with sterile distilled water at a proportion of $1 \mathrm{~g}$ of 
Table 1 - Factorial analysis of each disinfectant with each test material for the dependent variable $X_{50}$.

\begin{tabular}{|c|c|c|c|c|c|c|}
\hline \multirow{2}{*}{\multicolumn{2}{|c|}{ Material }} & \multirow{2}{*}{ Disinfectant } & \multicolumn{3}{|c|}{ Time (days) } & \multirow{2}{*}{ Average } \\
\hline & & & 1 & 15 & 60 & \\
\hline \multirow{5}{*}{\multicolumn{2}{|c|}{ Optosil }} & None & 3.52 & 3.54 & 3.40 & 3.48 \\
\hline & & Glutaraldehyde & 3.32 & 3.33 & 3.57 & 3.41 \\
\hline & & Chlorhexidine & 3.12 & 3.05 & 3.49 & 3.22 \\
\hline & & Alcohol 70\% & 3.22 & 2.86 & 3.30 & 3.13 \\
\hline & & Hypochlorite & 2.34 & 3.13 & 3.55 & 3.01 \\
\hline \multirow{5}{*}{\multicolumn{2}{|c|}{ Optocal }} & None & 3.52 & 3.34 & 3.25 & 3.37 \\
\hline & & Glutaraldehyde & 3.32 & 3.30 & 3.35 & 3.32 \\
\hline & & Chlorhexidine & 3.12 & 3.03 & 3.06 & 3.07 \\
\hline & & Alcohol 70\% & 3.21 & 2.86 & 2.80 & 2.96 \\
\hline & & Hypochlorite & 2.84 & 3.13 & 3.13 & 3.03 \\
\hline \multirow{5}{*}{\multicolumn{2}{|c|}{ Zetaplus }} & None & 3.10 & 3.24 & 3.03 & 3.12 \\
\hline & & Glutaraldehyde & 3.99 & 3.65 & 3.85 & 3.83 \\
\hline & & Chlorhexidine & 4.02 & 3.98 & 4.07 & 4.02 \\
\hline & & Alcohol 70\% & 3.96 & 4.15 & 4.20 & 4.10 \\
\hline & & Hypochlorite & 3.88 & 3.74 & 3.84 & 3.82 \\
\hline \multirow{6}{*}{\multicolumn{2}{|c|}{ Perfil }} & None & 8.21 & 7.71 & 8.25 & $8.05 b$ \\
\hline & & Glutaraldehyde & 6.56 & 6.34 & 6.75 & $6.55 a$ \\
\hline & & Chlorhexidine & 7.32 & 7.93 & 7.53 & $7.59 \mathrm{~b}$ \\
\hline & & Alcohol 70\% & 6.15 & 6.21 & 6.04 & $6.13 a$ \\
\hline & & Hypochlorite & 6.16 & 6.70 & 6.72 & $6.53 a$ \\
\hline & & VC (\%) & 8.70 & & & \\
\hline \multicolumn{7}{|c|}{ Probabilities } \\
\hline M & $\mathrm{D}$ & $M * D$ & $\mathrm{~T}$ & $\mathrm{~T}^{*} \mathrm{M}$ & $T * D$ & $T^{*} M^{*} D$ \\
\hline 0 & 0.047 & 0.0037 & 0.5877 & 0.9031 & 0.8994 & 0.9999 \\
\hline
\end{tabular}

VC: variance coefficient; M: material; D: disinfectant; T: time. ${ }^{a, b, c}$ Different superscript letters correspond to significant differences between lines.

block per $2 \mathrm{~mL}$ of water. The mixture was agitated in a Vortex agitator for 30 seconds, and $25 \mu \mathrm{L}$ of the solution were inoculated into Petri dishes containing MITIS medium (Mitis salivarius-bacitracin; Acumedia Manufacturers, Inc., Baltimore, USA). The plates were incubated for 3 days at $37^{\circ} \mathrm{C}$ in microaerophilic conditions. The colony forming units (CFUs) were characterized and counted $(\mathrm{CFU} / \mathrm{mL})$ on the basis of the presence of white/grey color and ground glass aspect of the colonies. This method was only used as biological marker of the presence of viable microorganisms in the samples stored over time.

Statistical analysis involved an entirely random design in a $4 \times 4+1$ factorial outline (four test materials and four disinfection products +1 control) with a portion divided by the time ( 24 hours, 15 days, and 60 days). The data were submitted to variance analysis, with the averages being compared among themselves by the Tukey test (5\%). The data were subjected to the square-root transformation for normalization. For the CFU, the nonparametric statistical analysis (chi-square) was used, and the averages were compared by the Kruskal-Wallis test with the SAS statistical package (1996).

\section{Results}

No differences in the $\mathrm{X}_{50}$ values were observed between the periods studied or between the aspersion and immersion methods. Therefore, the re- 
Table 2 - Factorial analysis of each test material with each disinfectant for the dependent variable $\mathrm{X}_{50}$.

\begin{tabular}{|c|c|c|c|c|c|c|}
\hline \multirow{2}{*}{\multicolumn{2}{|c|}{ Disinfectant }} & \multirow{2}{*}{ Material } & \multicolumn{3}{|c|}{ Time (days) } & \multirow{2}{*}{ Average } \\
\hline & & & 1 & 15 & 60 & \\
\hline \multirow{4}{*}{\multicolumn{2}{|c|}{ None }} & Optosil & 3.52 & 3.54 & 3.40 & $3.48 a$ \\
\hline & & Optocal & 3.52 & 3.34 & 3.25 & $3.37 a$ \\
\hline & & Zetaplus & 3.10 & 3.24 & 3.03 & $3.12 a$ \\
\hline & & Perfil & 8.21 & 7.71 & 8.25 & $8.05 b$ \\
\hline \multirow{4}{*}{\multicolumn{2}{|c|}{ Glutaraldehyde }} & Optosil & 3.32 & 3.33 & 3.57 & $3.41 \mathrm{a}$ \\
\hline & & Optocal & 3.32 & 3.30 & 3.35 & $3.32 a b$ \\
\hline & & Zetaplus & 3.99 & 3.65 & 3.85 & $3.83 \mathrm{~b}$ \\
\hline & & Perfil & 6.56 & 6.34 & 6.75 & $6.55 c$ \\
\hline \multirow{4}{*}{\multicolumn{2}{|c|}{ Chlorhexidine }} & Optosil & 3.12 & 3.05 & 3.49 & $3.22 \mathrm{a}$ \\
\hline & & Optocal & 3.12 & 3.03 & 3.06 & $3.07 \mathrm{a}$ \\
\hline & & Zetaplus & 4.02 & 3.98 & 4.07 & $4.02 \mathrm{~b}$ \\
\hline & & Perfil & 7.32 & 7.93 & 7.53 & $7.59 \mathrm{c}$ \\
\hline \multirow{4}{*}{\multicolumn{2}{|c|}{ Alcohol 70\% }} & Optosil & 3.22 & 2.86 & 3.30 & $3.13 a$ \\
\hline & & Optocal & 3.21 & 2.86 & 2.80 & $2.96 a$ \\
\hline & & Zetaplus & 3.96 & 4.15 & 4.20 & $4.10 \mathrm{~b}$ \\
\hline & & Perfil & 6.15 & 6.21 & 6.04 & $6.13 c$ \\
\hline \multirow{5}{*}{\multicolumn{2}{|c|}{ Hypochlorite }} & Optosil & 2,34 & 3.13 & 3.55 & $3.01 \mathrm{a}$ \\
\hline & & Optocal & 2.84 & 3.13 & 3.13 & $3.03 a$ \\
\hline & & Zetaplus & 3.88 & 3.74 & 3.84 & $3.82 \mathrm{~b}$ \\
\hline & & Perfil & 6.16 & 6.70 & 6.72 & $6.53 c$ \\
\hline & & VC (\%) & 8.70 & & & \\
\hline \multicolumn{7}{|c|}{ Probabilities } \\
\hline$M$ & $D$ & $M^{*} \mathrm{D}$ & $\mathrm{T}$ & $T^{*} M$ & $T^{*} \mathrm{D}$ & $\mathrm{T}^{*} \mathrm{M} * \mathrm{D}$ \\
\hline 0 & 0.0047 & 0.0037 & 0.5877 & 0.9031 & 0.8994 & 0.9999 \\
\hline
\end{tabular}

VC: variance coefficient; M: material; D: disinfectant; T: time. a,b,c Different superscript letters correspond to significant differences between lines.

maining analyses were conducted by combining the aspersion and immersion samples. There was interaction $(p<0.05)$ between the disinfectant type and the test material; however, there was no influence of the time (Table 1). When Perfil was used as a test material, chlorhexidine presented the worst result. Perfil showed the highest values for particle size $(p<0.05)$ in all the tested disinfectants, with Optosil and Optocal showing the best results (Table 2).

Data related to the CFU counts are presented in Table 3. The CFU count differed between the nondisinfected group and all other disinfection groups at all moments $(p<0.01)$. No other significant differences in the CFU counts were observed between the disinfection groups.

The time factor and disinfection type (immersion versus aspersion) had no influence on the MP or the number of CFUs $(p>0.05)$.

\section{Discussion}

The MP is determined according to an individual's capacity to fragment a test food..$^{1,11,15,21}$ Protocols for the MP test in the literature use various test foods, and an individual's masticatory power limits the determination of MP. Due to the difficulty of establishing precise evaluations in debilitated patients (e.g., total prosthesis wearers), new methods and different test foods for the MP test have been 
Table 3 - Factorial analysis of each disinfectant with each test material for colony forming units (CFUs).

\begin{tabular}{|c|c|c|c|c|c|}
\hline \multirow{2}{*}{ Material } & \multirow{2}{*}{ Disinfectant } & \multicolumn{3}{|c|}{ Time (days) } & \multirow{2}{*}{ Average } \\
\hline & & 0 & 15 & 60 & \\
\hline \multirow{5}{*}{ Optosil } & None & 18.25 & 5 & 2.25 & $8.5^{*}$ \\
\hline & Glutaraldehyde & 0.00 & 0.00 & 1.88 & 0.63 \\
\hline & Chlorhexidine & 0.00 & 0.00 & 0.75 & 0.25 \\
\hline & Alcohol 70\% & 0.00 & 0.00 & 0.00 & 0.00 \\
\hline & Hypochlorite & 0.00 & 0.00 & 6.50 & 2.17 \\
\hline \multirow{5}{*}{ Optocal } & None & 1000 & 790 & 541.5 & $777.16^{*}$ \\
\hline & Glutaraldehyde & 0.00 & 0.00 & 0.00 & 0.00 \\
\hline & Chlorhexidine & 0.00 & 0.25 & 0.00 & 0.08 \\
\hline & Alcohol 70\% & 10.63 & 0.13 & 0.88 & 3.88 \\
\hline & Hypochlorite & 0.00 & 0.00 & 0.13 & 0.04 \\
\hline \multirow{5}{*}{ Zetaplus } & None & 0.25 & 3 & 700 & $234.41^{*}$ \\
\hline & Glutaraldehyde & 0.00 & 0.13 & 6.00 & 2.04 \\
\hline & Chlorhexidine & 0.00 & 0.38 & 0.00 & 0.13 \\
\hline & Alcohol 70\% & 3.63 & 0.00 & 12.63 & 5.42 \\
\hline & Hypochlorite & 0.25 & 0.00 & 0.00 & 0.08 \\
\hline \multirow{5}{*}{ Perfil } & None & 18.75 & 42.75 & 172.25 & $77.91^{*}$ \\
\hline & Glutaraldehyde & 0.00 & 5.25 & 0.00 & 1.75 \\
\hline & Chlorhexidine & 0.13 & 0.00 & 0.00 & 0.04 \\
\hline & Alcohol 70\% & 0.00 & 0.13 & 0.00 & 0.04 \\
\hline & Hypochlorite & 0.13 & 0.00 & 0.75 & 0.29 \\
\hline
\end{tabular}

* Control: different from others by the Kruskal-Wallis test $(p<0.05)$.

employed. ${ }^{22}$ Thus, it is important to study different test materials for MP determination, and the use of appropriate materials for different patient profiles is important from a clinical perspective.

Variations in the form, size, and hardness of foods produce differences in the tests, thereby influencing the final results. ${ }^{23}$ Different test foods also present variations in consistency, due to the incorporation of water originating from the saliva. These variations can render the standardization and the conduction of masticatory tests difficult. Condensation silicone was proposed as a pioneer chewable artificial test material for the evaluation of masticatory function..$^{18}$ For example, the condensation silicone Optosil is almost odorless and tasteless, does not incorporate water, and can be maintained for up to 7 days without undergoing any important dimensional alterations when used for molding applications. Samples of this elastomeric material can be easily standardized and appraised after mastication, allowing weight and size control, thus reducing variability during production and mastication tests. ${ }^{17}$

Among the materials employed in the present study, Perfil presented significantly higher $\mathrm{X}_{50}$ values than the other materials. This result can be justified by the fact that Perfil presented a Shore A of 80 after 24 hours. As a result, it displayed greater hardness and higher resistance to mastication than the other materials and, consequently, was not easily fragmented. The fragments of Perfil were larger and were retained in the upper portions of the sieve sequence. In spite of being an inexpensive and easily accessible test material, use of Perfil may lead to MP values that are incompatible with the international literature.

Optocal is a variation of Optosil that displays reduced consistency, for use with debilitated patients or those with low masticatory capacity. ${ }^{17,21}$ 
Optocal presented the lowest $\mathrm{X}_{50}$ value among the 4 test foods investigated, followed by Optosil. The primary advantage of Optocal is its flexible and malleable consistency. ${ }^{17}$ Nevertheless, some studies have shown that this material is still not sufficiently soft for children and for oncological patients with temporomandibular disorders. ${ }^{23}$ The mixture capacity test has been considered to be more appropriate than the fragmentation test for measuring differences in MP in individuals with compromised oral function. ${ }^{23}$ The Zetaplus material presented reports of a gritty sensation.

In this study, the disinfection method did not appear to alter the calculated $\mathrm{X}_{50}$. We recommend that disinfection of the MP test material be conducted, to avoid contamination of the experimenter due to contact with the patient's saliva. After being taken into the mouth, elastomers can store viral particles and should be considered as infectocontagious disease transmission vehicles. Washing removes some of the microbial flora; however, pathogenic microorganisms can remain on the elastomer surface. ${ }^{24,25}$ Therefore, the test foods should be disinfected.

The samples were evaluated at different time periods to reflect the fact that an experimenter may have to collect several samples and may be away from his or her laboratory/dental office. The time elapsed between sample collection and weight measurement could result in differences in MP determination. Besides, samples are often stored in the laboratory. As a result, they could present fungal growth, which

\section{References}

1. Pereira LJ, Gavião MBD, van der Bilt A. Influence of oral characteristics and food products on masticatory function. Acta Odontol Scand. 2006 Aug;64(4):193-201.

2. van der Bilt A, Engelen L, Abbink J, Pereira LJ. Effects of adding fluids to solid foods on muscle activity and number of chewing cycles. Eur J Oral Sci. 2007 Jun;115(3):198-205.

3. van der Bilt A. Assessment of mastication with implications for oral rehabilitation: a review. J Oral Rehabil. 2011 Oct;38(10):754-80.

4. Bartali B, Salvini S, Turrini A, Lauretani F, Russo CR, Corsi AM, et al. Age and disability affect dietary intake. J Nutr. 2003 Sep;133(9):2868-73.

5. Roininem K, Fillion L, Kilcast D, Lähteenmäki L. Exploring difficult textural properties of fruit and vegetables for the could change the weight of the sample.

Disinfection with sodium hypochlorite or glutaraldehyde was previously found to have no significant effect on the dimensional stability of elastomers used in moldings. ${ }^{26}$ The present findings corroborate these previous results, demonstrating that disinfection does not lead to important alterations in the weights of samples used for MP determination. However, the use of glutaraldehyde is currently forbidden in numerous countries. Contact of the skin and mucosa with glutaraldehyde may produce inflammation, and handling without appropriate exposure to air may cause respiratory illness. ${ }^{27}$

Disinfection methods are indicated when an individual has contact with saliva, because oral and respiratory passage infections can result from the transfer of pathogenic bacteria strains, such as streptococci, staphylococci, and pneumococcus, among others. ${ }^{28}$ Hepatitis B virus can survive in $42 \%$ humidity for 7 days, ${ }^{29}$ and Staphylococcus aureus can survive on dry surfaces for an average of 5 days. ${ }^{30}$

\section{Conclusion}

Disinfection for up to 60 days did not alter the reliability of the test foods for the MP calculation.

\section{Acknowledgments}

The authors are grateful to the Research Support Foundation of the State of Minas Gerais (FAPEMIG) and the National Council for Scientific and Technological Development (CNPq).

elderly in Finland and the United Kingdom. Food Qual Prefer. 2004 Sep;15(6):517-30.

6. Sheiham A, Steele JG, Marcenes W, Lowe C, Finch S, Bates CJ, et al. The relationship among dental status, nutrient intake, and nutritional status in older people. J Dent Res. 2001 Feb;80(2):408-13.

7. Takata Y, Ansai T, Awano S, Fukuhara M, Sonoki K, Wakisaka $\mathrm{M}$, et al. Chewing ability and quality of life in an 80-yearold population. J Oral Rehabil. 2006 May;33(5):330-34.

8. Bates JF, Stafford GD, Harrison A. Masticatory function - a review of the literature. III. Masticatory performance and efficiency. J Oral Rehabil. 1976 Jan;3(1):57-67.

9. van der Bilt A, Abbink JH, Mowlana F, Heath MR. A comparison between data analysis methods concerning particle 
size distributions obtained by mastication in man. Arch Oral Biol. 1993 Feb;38(2):163-7.

10. Fontijn-Tekamp FA, van der Bilt A, Abbink JH, Bosman F. Swallowing threshold and masticatory performance in dentate adults. Physiol Behav. 2004 Dec 15;83(3):431-6.

11. Matos LF, Pereira SM, Kaminagakura E, Marques LS, Pereira $\mathrm{CV}$, van der Bilt A, et al. Relationships of beta-blockers and anxiolytics intake and salivary secretion, masticatory performance and taste perception. Arch Oral Biol. 2010 Feb;55(2):164-9.

12. Gambareli FR, Serra MD, Pereira LJ, Gavião MBD. Influence of measurement technique, test food, teeth and muscle force interactions in masticatory performance. J Texture Stud. 2007;38(1):2-20.

13. Memarian M, Fazeli MR, Jamalifar H, Azimnejad A. Disinfection efficiency of irreversible hydrocolloid impressions using different concentrations of sodium hypochlorite: a pilot study. J Contemp Dent Pract. 2007 May 1;8(4):27-34.

14. Kohn WG, Collins AS, Cleveland JL, Harte JA, Eklund KJ, Malvitz DM, et al. Guidelines for infection control in dental health-care settings--2003. MMWR Recomm Rep. 2003 Dec;19;52(RR-17):1-61.

15. Pereira LJ, Gazolla CM, Magalhães IB, Ramos-Jorge ML, Marques LS, Gameiro GH, et al. Treatment of chronic periodontitis and its impact on mastication. J Periodontol. 2011 Feb;82(2):243-50.

16. Slagter AP, Bosman F, van der Bilt A. Comminution of two artificial test foods by dentate and edentulous subjects. J Oral Rehabil. 1993 Mar;20(2):159-76.

17. Pocztaruk RL, Frasca LC, Rivaldo EG, Fernandes EL, Gavião MB. Protocol for production of a chewable material for masticatory function tests (Optocal - Brazilian version). Braz Oral Res. 2008 Oct-Dec;22(4):305-10.

18. Slagter AP, Bosman F, van der Glas HW, van der Bilt A. Human jaw-elevator muscle activity and food comminution in the dentate and edentulous state. Arch Oral Biol. 1993 Mar;38(3):195-205.

19. Slagter AP, Olthoff LW, Bosman F, Steen WH. Masticatory ability, denture quality, and oral conditions in edentulous subjects. J Prosthet Dent. 1992 Aug;68(2):299-307.
20. van der Bilt A, Olthoff LW, Bosman F, Oosterhaven SP. Chewing performance before and after rehabilitation of post-canine teeth in man. J Dent Res. 1994 Nov;73(11):1677-83.

21. Pereira LJ, Steenks MH, de Wijer A, Speksnijder CM, van der Bilt A. Masticatory function in subacute TMD patients before and after treatment. J Oral Rehabil. 2009 Jun;36(6):391-402.

22. van der Bilt A, Mojet J, Tekamp FA, Abbink JH. Comparing masticatory performance and mixing ability. J Oral Rehabil. 2010 Feb;37(2):79-84.

23. Speksnijder CM, Abbink JH, van der Glas HW, Janssen NG, van der Bilt A. Mixing ability test compared with a comminution test in persons with normal and compromised masticatory performance. Eur J Oral Sci. 2009 Oct;117(5):580-6.

24. Naylor WP. Infection control in fixed prosthodontics. Dent Clin North Am. 1992 Jul;36(3):809-31.

25. Infection control recommendations for the dental office and the dental laboratory. ADA Council on Scientific Affairs and ADA Council on Dental Practice. J Am Dent Assoc. 1996 May;127(5):672-80.

26. Can G, Ozmen G. [Effect of disinfection on linear and dimensional stability of impression materials]. Ankara Univ Hekim Fak Derg. 1989 May;16(1):65-70. Turkish.

27. Orsi IA, Andrade VG, Bonato PS, Raimundo LB, Herzog DS, Borie E. Glutaraldehyde release from heat-polymerized acrylic resins after disinfection and chemical and mechanical polishing. Braz Dent J. 2011;22(6):490-6.

28. Klein RS, Phelan JA, Freeman K, Schable C, Friedland GH, Trieger N, et al. Low occupational risk of human immunodeficiency virus infection among dental professionals. N Engl J Med. 1988 Jan 14;318(2):86-90.

29. Bond WW, Favero MS, Petersen NJ, Gravelle CR, Ebert JW, Maynard JE. Survival of hepatitis B virus after drying and storage for one week. Lancet. 1981 Mar 7;1(8219):550-1.

30. Getchell-White SI, Donowitz LG, Groschel DHM. The inanimate environment of an intensive care unit as a potential source of nosocomial bacteria: evidence for long survival of Acinetobacter calcoaceticus. Infect Control Hosp Epidemiol. 1989 Sep;10(9):402-7. 